\section{Long Term Remission of Hyper IgE Syndrome after Treatment with Cyclosporine- A: Clinic and Immunological Correlations}

\author{
Harb A Harfi ${ }^{1,3 *}$, Ranjit S Parhar ${ }^{2}$ and Sultan Al Sedairy ${ }^{2}$ \\ ${ }^{1}$ Department of Pediatrics \& Medicine, National Center of Allergy, Asthma \\ and Immunology (NCAAI), Riyadh, Saudi Arabia
}

${ }^{2}$ Department of Biological \& Medical Research, National Center of Allergy, Asthma and Immunology (NCAAl), Riyadh, Saudi Arabia

${ }^{3}$ North King Faisal Hospital \& Research Centre, Riyadh, Saudi Arabia

\begin{abstract}
Hyper IgE syndrome is characterized by recurrent staphylococcal abscess, sinopulmonary infection, severe eczema and extremely high level of IgE. Recent work revealed a broader array of clinical features with defects in immune regulations. Management of these patients is very difficult because the pathophysiology of the immunodeficiency has not been completely elucidated. We examined the effect of a small dose of Cyclosporin-A (CSA) on the clinical course, and the excessive production of $\mathrm{IgE}$ and other immunologic parameters and infection in patients with Hyper IgE (HIE) syndrome.

Three patients, two females and one male, two were brother and sister; their ages were between 10 months and three years. All three patients were suffering from severe eczema, recurrent sinopulmonary infection, lung and skin abscesses, chronically draining ear and

*Corresponding author: Harb A Harfi, National Center of Allergy, Asthma and Immunology (NCAAI), North King Faisal Hospital and Research Centre, Riyadh, Saudi Arabia, Tel: +966 114803333; Fax: + 966 114800480; E-mail: harfi@allergyarabia.com; hharfi@icloud.com
\end{abstract}

Citation: Harfi HA, Parhar RS, al-Sedairy S (2019) Long Term Remission of Hyper IgE Syndrome after Treatment with Cyclosporine-a: Clinic and Immunological Correlations. J Allergy Disord Ther 5: 009.

Received: November 14, 2018; Accepted: January 7, 2019; Published: January 21, 2019

Copyright: () 2019 Harfi HA, et al. This is an open-access article distributed under the terms of the Creative Commons Attribution License, which permits unrestricted use, distribution, and reproduction in any medium, provided the original author and source are credited. failure to thrive since the first few weeks of their lives. Their serum $\mathrm{lgE}$ was more than 10 times upper normal for age. Measurement of serum IgE, Cytokine IL-4, and IFN- $\gamma$ and serum immunoglobulins measure before and after treatment, in addition, skin score of dermatitis and the number of infection, were evaluated before and after treatment with CSA.

Following treatment with CSA, 2-4 mg/kg per day in 2 divided doses, after standard treatment failed. There was a dramatic and sustained clinical improvement, especially dermatitis, associated with marked drop in serum IgE $(P<0.0001), I L-4(P<0.0001)$, and IFN-Y $(P<0.001)$. There was no significant change in serum levels of IgG, $\operatorname{lgA}$ and IgM. The results of our study indicate that immune imbalance in HIE syndrome can be modulated by CSA that leads to marked drop on IgE and IL-4 synthesis and clinical remission. This treatment needs to be repeated in a larger number of patients.

Keywords: Cyclosporin-A; Cytokines; Dermatitis; Hyper IgE syndrome; Immunodeficiency; Interleukin-4

\section{Introduction}

The Hyper IgE (HIE) syndrome is a rare and complex disorder characterized by high serum IgE, chronic eczematoid dermatitis, recurrent sinopulmonary infections and skin abscesses [1]. The precise incidence is not known, with an estimated incidence ranging from 1 in 500,000 to 1 in 100,000 individuals. It is found equally in males and females, Caucasian, Asian and African [2,3]. The clinical features reported in 85 patients were as follows: skin abscesses $74 \%$, eczema $58 \%$, retained primary teeth $41 \%$, fractures $39 \%$, scoliosis $34 \%$, and cancer 7\% [4]. Recent studies have demonstrated that Peripheral Blood Mononuclear Cells (PBMCS) from HIE patients produce excessive IgE in vitro, spontaneously [5]. In addition, there is evidence that recombinant interleukin-4 (IL-4) induces IgE production in an unfractionated Peripheral Blood Mononuclear Cells (PBMC), which is enhanced by IL-2, IL- 5 and IL- 6 and suppressed by IFN- $\alpha$, IFN- $\gamma$ and $\mathrm{PGE}_{2}$ [6]. However, no immediate causal relationship could be established between increased production of $\operatorname{IgE}$ and lymphokines secretion and the clinical course in HIE syndrome [7]. This leaves the etiology and pathogenesis of recurrent infections, increased serum IgE levels and eczematoid dermatitis in this syndrome poorly understood. However, recent studies showed that in the autosomal dominant and related disorders are due to defect in the Janus activated Kinase-signal transducer and activator of transcription (JAK-STAT) signaling pathway that is activated by cytokines, such as IL- 6 and IL-2 [8].

Treatment of HIE patients is frustrating and remains largely unsuccessful. Several treatment modalities have been tried with limited and often temporary success [9-15]. Because HIE patients have excessive production of IgE and IL-4, clinical improvement may be achieved by down regulation of IgE and IL-4. Therefore, we conducted a prospective clinical immunological study to assess the effect of small doses of Cyclosporin-A (CSA) on the clinical course, especially dermatitis and skin infection in HIE syndrome. Three patients with the HIE syndrome showed remarkable clinical improvement following 
treatment with a small dose of CSA $2-4 \mathrm{mg} / \mathrm{kg}$ per day. There was remarkable and significant drop in serum IgE, IL-4 and IFN- $\gamma$ without affecting immunoglobulin levels after treatment compared to pre-treatment. Our study suggests that the clinical manifestations, especially dermatitis, may be related partially to the high levels of IL-4 and IgE levels which can be modulated by CSA. But these patients have many genetic defect in production of cytokines such as Th17 and IFN-gamma which impairs neutrophils, chemotaxis and IFN-gamma injections reduce the frequency of skin and lung infections $[3,16]$. Several immunological and pathological abnormalities have been observed in these patients including immunodeficiency markers such as elevated IgD levels, decreased IgG subclasses and poor response to both protein and polysaccharides immunization $[16,17]$. Some of these patients have symptoms of allergy to foods in $38 \%$ and anaphylaxis $8 \%$ [18]. These complex immunopathological abnormalities make management of these patients difficult.

\section{Materials and Methods}

\section{Patients}

Three children randomly selected who were diagnosed to have HIE syndrome according to the criteria defined by Buckley and Becker, were studied. There were two females and one male; two were a brother and sister [1]. Their ages ranged between 10 months and three years at the time of enrollment in the study. All patients had history of extensive dermatitis and recurrent staphylococcal abscesses of skin and lungs, sinusitis, and chronically draining ears since the first few weeks of life and they failed to thrive. They had serum IgE levels at least ten times the upper normal for age.

\section{Scoring of skin inflammation}

To assess the severity of dermatitis and the degree of inflammation prior to and during treatment with cyclosporin-A, a scoring system of $0-4$ was used. $0=$ no dermatitis or inflammation, $1=$ mild dermatitis without infection on a small area of the skin, $2=$ mild dermatitis involving less than $50 \%$ of the skin but no infection, $3=$ extensive dermatitis involving most or all the skin but no infection or abscess formation, and $4=$ the same as 3 but with superimposed infection and/ or abscess formation.

\section{Routine laboratory investigations}

All patients had complete blood count and differential, hepatic and renal profile, surface and lesion cultures, chest and sinus X-ray at the time of admission and during the study period.

\section{Treatment protocol}

Patients were treated with appropriate antibiotics whenever indicated, antihistamines to control pruritus and topical and, at times, systemic steroids to controls skin inflammation. After the above measures failed, patients were started on oral cyclosporin-A, at a dose of 2-4 $\mathrm{mg} / \mathrm{kg}$ per day in two divided doses. Serum CSA was monitored to keep the trough level between 60 and $200 \mu \mathrm{g} / \mathrm{ml}$.

\section{Serum IgE, IgG and IgA quantitation}

Serum IgE was measured by Phadezym IgE PRIST using ELISA kit (Pharmacia, Uppsala, Sweden). IgG, IgM and IgA were measured by ACA Discrete Clinical Analyzer (Dupont, Wilmington, DE, USA).

\section{Immunological studies}

The following immunological investigations were carried out before and after CSA treatment i.e.,

- Immunophenotyping using Flow Cytometric Cell Analysis (FACS)

- Mitogenic response of PBMC to Phytohemagglutinin (PHA), Pokeweed Mitogen (PWM) and cytokine IL-2

- Natural Killer (NK) cell function

- Cytokine level of IL- $\alpha$, IL-2, TNF- $\alpha$, IFN- $\gamma$ and IL-4

\section{Isolation of PBMC from whole Blood}

Whole peripheral blood from patients and normal healthy young individuals were collected into heparinized tubes. PBMCs were isolated by subjecting it to Ficoll-Hypaquegradient fractionation [19]. The isolated PBMC were washed twice with medium RPMI-1640 and finally suspended into complete medium in RPMI-1640, supplemented with Hepes $25 \mathrm{mM}$, L-glutamine $25 \mathrm{mM}, 5 \%$ human $\mathrm{AB}$ serum, penicillin $(100 \mathrm{U} / \mathrm{ml})$, streptomycin $(100 \mu \mathrm{g} / \mathrm{ml})$ and fungizone $(20$ $\mu \mathrm{g} / \mathrm{ml}$ ) (Flow Laboratories, McLean, VA, USA). Cell counts and cell viability were judged by trypan blue dye $(0.02 \%)$ exclusion method. PBMC with at least $\geq 98 \%$ viability were used in the experiments.

\section{Mitogens PHA and PWM Induced stimulation of PBMC}

$10^{5}$ PBMC either from normal subjects or patients with Hyper IgE (HIE) syndrome, were cultured in quadruplicate in 96 well round bottom microtiter plate in a final volume of $250 \mu \mathrm{l}$ complete RPMI-1640 containing $5 \mu \mathrm{g} / 10^{6} / \mathrm{ml}$ of PHA or PWM (Flow Lab, McLean, VA, USA) for 72 hours. The proliferation response was measured from the $\left[{ }^{3} \mathrm{H}\right]$ Thymidine $\left[{ }^{3} \mathrm{HTdR}\right]$ uptake after an 18 hour pulse.

$(1 \mu \mathrm{Ci} /$ well Sp. activity $6.7 \mu \mathrm{Ci} / \mathrm{mM})$ as given by the $\beta$ counts of cultures harvested with a cell harvester (Titretek Flow Labs, Rockville, MD) [20].

\section{Interleukin-2 dependent proliferation of PBMC}

As previously described, $10^{5}$ PBMC either from normal individuals or hyper IgE patients were cultured in the presence of $100 \mathrm{U}$ of recombinant IL-2 (Genzyme, Boston, MA, USA) for 72 hours. The proliferative response, ${ }^{3} \mathrm{HTdR}$ uptake was then measured [21].

\section{Natural Killer (NK) cell assay}

This was performed using a standard 4 hour $51 \mathrm{Cr}$ release assay as previously described [22]. K562 erythroleukemia (NK sensitive) cells were labeled with Sodium Chromate and used as target for normal or patients PBMC (effector cells) at various 12:5:1 to 100:1, effector:target ratio.

The percent specific cytotoxicity was computed as follows:

$$
\% \text { Specific Cytotoxicity }=\frac{{ }^{51} \mathrm{cr} C P M \text { Experimental release }-{ }^{51} \mathrm{cr} C P M \text { Spon } \tan \text { eous release }}{{ }^{51} \mathrm{cr} \text { CPM Maximum release }-{ }^{51} \mathrm{cr} C P M \text { Spon tan eous release }} \times 100
$$

\section{Quantitations of cytokines}

As earlier described Interleukin-1 $\alpha$ (IL-1 $\alpha$ ), Interleukin-2 (IL-2), Interferon- $\gamma$ (IFN- $\gamma$ ), Tumour Necrosis Factor- $\alpha$ (TNF- $\alpha)$ and Interleukin-4 (IL-4) were measured from the plasma samples of HIE patients and normal individuals using highly sensitive ELISA kits from 
Endogen MA, USA, (IL- $\alpha$, TNF- $\alpha$ ), Genzyme MA, USA, (IL-2), Holland Biotechnology (IFN- $\gamma$ ) and R\&D System MN, USA, (IL-4). Manufacturer's guidelines were followed in carrying out the measurements of these cytokines [23].

\section{Flow Cytometric (FACS) analysis}

Heparinized blood was used to quantify various populations and subsets of lymphocytes using fluorescent-phycoerythrin conjugated monoclonal antibodies (FITC/PE-MOAbs Becton-Dickinson CA, USA). Cells were labeled with FITC or PE-MOAbs $\mathrm{Leu}^{4} / 12, \mathrm{Leu}^{3} / 2$, $\mathrm{Leu}^{4} / \mathrm{DR}, \mathrm{Leu}^{7} / 2, \mathrm{Leu}^{3} / 8, \mathrm{Leu}^{4} / 11+19$ for 30 minutes at $4^{\circ} \mathrm{C}, \mathrm{RBC}$ were lysed and cells were fixed in PBS containing 1\% paraformaldehyde. Percent positive cells for various surface markers were analyzed using FAC Scan (Becton-Dickinson CA, USA) [22].

\section{Statistical evaluation}

The results were expressed as mean \pm SE Statistically, significance of difference between various experimental groups was tested using one way analysis of variance and students $t$ test. $p$ value at $\leq 0.05$ was considered significance.

\section{Results}

All three patients met the criteria of HIE diagnosis. Their serum IgE levels ranged between 5,400 and 38,400 (normal 3.84-72 $\mu \mathrm{g} / \mathrm{L}$ ) at the time of diagnosis and before starting treatment with CSA. All patients required repeated hospitalization for treatment of infections and/or surgical drainage of skin abscesses. One patient had keratoconjunctivitis and lost one eye of pseudomonas infection. The other two had mucocutaneous candidiasis. They also had chronic sinusitis and bronchiectasis. Staphylococcus aureus was cultured from all lesions. Their peripheral blood count showed significant eosinophilia (23-65\%). Specific IgE antibody measurement in vitro by RAST scores were 3-4 against milk, eggs and wheat. None of the patients experienced respiratory allergies, although one patient had wheezing episodes during lung infections.

Patients No 1 and 2 were sister and brother with negative family history of a similar condition. Patient No 3 had 6-year-old maternal cousin who died with identical history. The parents of all our patients (six other patients not reported here) were of consanguine marriage, usually first degree cousins (Figure 1).

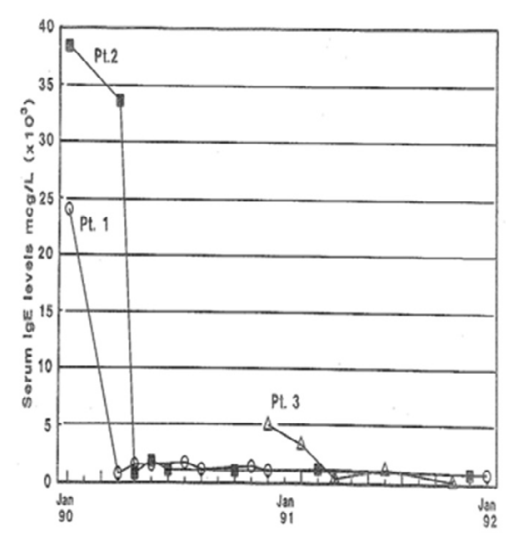

Figure 1: Hyper IgE levels in 3 patients with hyper IgE syndrome at the beginning and during treatment with cyclosporine-A.

\section{Response to Treatment}

On admission the skin score was 4 in all patients. There was little or insignificant response of antihistamines, skin emollients, steroids and repeated courses of antibiotics. There was a dramatic and a marked improvement within 72 hours of starting CSA treatment. Inflammation cleared up form most of the skin; skin scores dropped to 1-2 within 3 to 7 days after starting CSA. This improvement was constant and continued throughout the treatment course. Twenty-four months after starting CSA patients $1 \& 2$ and after 16 months, patient 3 continued to do well with minimal respiratory infections. This improvement coincided with a sharp and a significant drop in serum IgE levels. Serum IgG, IgA and IgM were not affected except patient no 1 where the posttreatment $\operatorname{IgG}$ level increased from 3 grams to 28 gram/L. In patient no 1 serum $\operatorname{IgE}$ level dropped from $24,000 \mu \mathrm{g}$ to $800 \mu \mathrm{g} / \mathrm{L}$ in 2 weeks, patient no 2 serum IgE dropped from $38,400 \mu \mathrm{g}$ to $864 \mu \mathrm{g} / \mathrm{L}$ in 7 weeks, while patient no 3 serum $\operatorname{IgE}$ level dropped from $5,040 \mu \mathrm{g}$ to $480 \mu \mathrm{g} / \mathrm{L}$ in 10 weeks. Although serum IgE levels stayed above the normal range, none of the patients had levels near the pre-treatment values (Table 1).

\section{Proliferative response $\left({ }^{3} \mathrm{HTdR}\right.$ uptake) to mitogens and cytokine}

PBMC from the hyper IgE patients showed impaired response to PHA and PWM as compared to control individuals with (3-37\%) suppression for PHA, and 4-43\% suppression for PWM. Similar suppression $(8 \%-22 \%)$ was also noted when PBMC from hyper IgE patients were co-cultured with interleukin-2 (Table 2).

\section{Analysis of Natural Killer (NK) cell function}

The results of NK assay performed with fresh PBMC of patients even at higher effector: target ratio (100:1) failed to demonstrate any appreciable level of cytotoxicity to K562 tumor target cells as compared to normal PBMC controls (Figure 2).

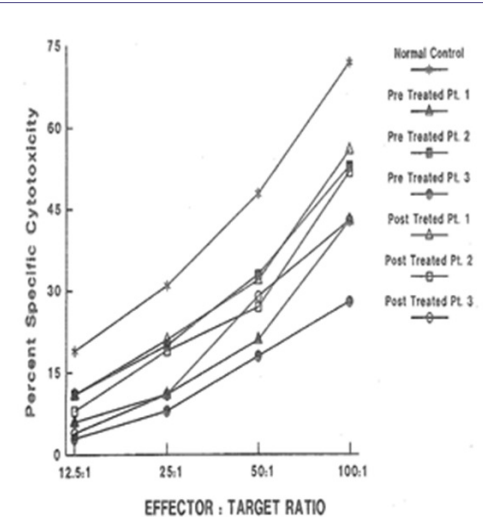

Figure 2: Functional Natural Killer (NK) cell assay of the HIE patients target cell KG62.

\section{Plasma level of cytokines}

The quantitation of cytokines prior to cyclosporin-A treatment indicated elevated level of IL-4 (112-147 units/ml), IFN- $\gamma$ (11-56 U/ $\mathrm{ml})$. Plasma level of IL-2 (results not presented), IL- $1 \alpha$ and TNF- $\alpha$ were either very low or not detected in any of the hyper IgE patients. A highly significant $(\mathrm{P}<0.0001)$ lower levels of IL-4 was observed in all post treated patients (Figures $3 \mathrm{a}$ and $3 \mathrm{~b}$ ). 
Citation: Harfi HA, Parhar RS, al-Sedairy S (2019) Long Term Remission of Hyper IgE Syndrome after Treatment with Cyclosporine-a: Clinic and Immunological Correlations. J Allergy Disord Ther 5: 009.

\begin{tabular}{|c|c|c|c|c|c|c|c|}
\hline \multirow[b]{2}{*}{ Patient } & \multirow[b]{2}{*}{ Age } & \multirow[b]{2}{*}{ Sex } & \multirow[b]{2}{*}{$\begin{array}{c}\text { Igs Normal Range } \\
(\mathrm{gm} / \mathrm{l})\end{array}$} & \multicolumn{4}{|c|}{$\begin{array}{l}\text { Serum } \\
(\mu \mathrm{g} / \mathrm{ml})\end{array}$} \\
\hline & & & & $\begin{array}{c}\text { IgG } \\
(4.4-12.9)\end{array}$ & $\begin{array}{c}\operatorname{IgA} \\
(0.4-1.2)\end{array}$ & $\begin{array}{c}\text { IIgM } \\
(0.2-1.7)\end{array}$ & $\begin{array}{c}\operatorname{IgE} \\
(3.84-72)\end{array}$ \\
\hline 1 & 2 years & F & $\begin{array}{l}\text { Pre-tr. } \\
\text { Post-tr. }\end{array}$ & $\begin{array}{c}3.0 \\
28.2\end{array}$ & $\begin{array}{l}0.6 \\
1.4\end{array}$ & $\begin{array}{l}0.4 \\
0.5\end{array}$ & $\begin{array}{c}24.000^{\mathrm{a}} \\
1.104^{\mathrm{a}}\end{array}$ \\
\hline 2 & 10 months & $\mathrm{M}$ & $\begin{array}{l}\text { Pre-tr. } \\
\text { Post-tr. }\end{array}$ & $\begin{array}{c}5.3 \\
13.3\end{array}$ & $\begin{array}{l}0.4 \\
1.3\end{array}$ & $\begin{array}{l}0.8 \\
1.4\end{array}$ & $\begin{array}{c}38.400^{\mathrm{a}} \\
888^{\mathrm{a}}\end{array}$ \\
\hline 3 & 3 years & F & $\begin{array}{l}\text { Pre-tr. } \\
\text { Post-tr. }\end{array}$ & $\begin{array}{l}13.2 \\
13.3\end{array}$ & $\begin{array}{l}2.6 \\
\text { ND }\end{array}$ & $\begin{array}{l}1.8 \\
1.2\end{array}$ & $\begin{array}{l}5.040^{\mathrm{a}} \\
211^{\mathrm{a}}\end{array}$ \\
\hline
\end{tabular}

Table 1: Serum IgE levels in 3 patients with HIE syndrome.

A highly significant difference $(\mathrm{P}<0.0001)$ in IgE plasma level was observed in all the 3 HIE-patients after CSA treatment. No statistical significant difference was observed in the level of IgM and IgA. Whereas significant difference $(\mathrm{P}<0.002$ Pt.1) was observed in IgG level.

\begin{tabular}{|c|c|c|c|c|}
\hline Patient & & PHAa & PWMa & IL-2b \\
\hline \multirow{2}{*}{1} & Pre-treatment & $42453 \pm 2363$ & $28112 \pm 1983$ & $49008 \pm 3097$ \\
\cline { 2 - 5 } & Post-treatment & $63017 \pm 2311$ & $50307 \pm 4763$ & $60946 \pm 1781$ \\
\hline \multirow{2}{*}{2} & Pre-treatment & $54583 \pm 1932$ & $43895 \pm 1108$ & $54034 \pm 3781$ \\
\cline { 2 - 5 } & Post-treatment & $64961 \pm 1851$ & $46388 \pm 3192$ & $59689 \pm 1673$ \\
\hline \multirow{2}{*}{3} & Pre-treatment & $55257 \pm 2117$ & $47348 \pm 3013$ & $54034 \pm 1907$ \\
\cline { 2 - 5 } & Post-treatment & $59387 \pm 3201$ & $46407 \pm 2011$ & $59921 \pm 2307$ \\
\hline & Normal Control $(\mathrm{n}=10)$ & $67387 \pm 3217$ & $49321 \pm 2703$ & $62831 \pm 3781$ \\
\hline
\end{tabular}

Table 1: HIE Patients PBL proliferative response [3HTdR CPM uptake] to mitogen or cytokine.

aPHA and PWM were used at $5 \mu \mathrm{g} / 1 \times 50^{6} \mathrm{PBL} / \mathrm{ml}$ concentration.

${ }^{b}$ Interleukin- 2 was used at $100 \mathrm{u} / 1 \times 10^{6} / \mathrm{PBL} / \mathrm{ml}$. $105 \mathrm{PBL} /$ well $/ 250 \mu \mathrm{g}$ were cultured for 72 hours at $37^{\circ}, 5 \% \mathrm{CO}_{2}$ and pulsed with $1 \mu$ ci3 HTdR for 18 hours before harvesting.
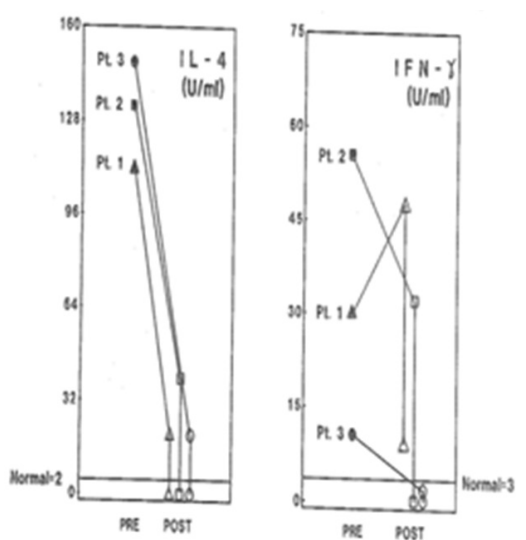

Figure 3a: Plasma level of cytokine IL-4 and IFN- $-\gamma$ before and after treatment with CSA in 3 patients with HIE syndrome.

\section{Flow cytometry analysis}

The absolute numbers of $\mathrm{T}$ and $\mathrm{B}$ lymphocytes did not demonstrate any significant changes other than that of normal controls. Whereas the number of $\mathrm{T}$ helper cells in all patients was substantially less as compared to normal individuals at the start of the treatment. The T4 (helper T cell): T8 (suppressors T cell) ratio was significantly
$(\mathrm{P}<0.05)$ less than normal Saudi controls. The T4:T8 ratio showed a significant increase after CSA treatment reflecting increase in $\mathrm{T}$ helper and decrease in T suppressor cell population. A higher degree of activated T cells (Leu4 /DR) were also found in all the patients (Table 3).

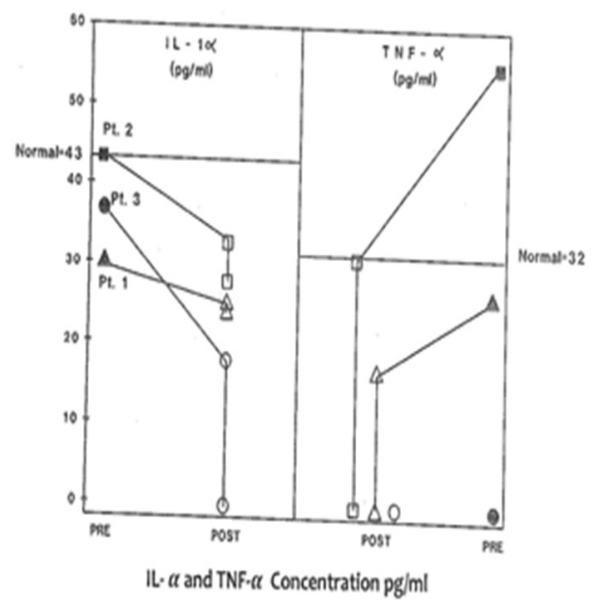

Figure 3b: Plasma level of cytokine IL- $\alpha$ and TNF- $\alpha$ before and after treatment with CSA in 3 patients with HIE syndrome. 


\begin{tabular}{|c|c|c|c|c|c|c|c|c|}
\hline \multirow{2}{*}{ Patients } & \multicolumn{8}{|c|}{ Percent Positive cells for various sub-populations of lymphocytes } \\
\hline & & $\mathrm{T}$ & B & $\mathrm{T} 4$ & T8 & Ratio & Act.T & $\mathrm{Nk}$ \\
\hline \multirow{2}{*}{1} & Pre-treatment & 70 & 18 & 17 & 44 & $0.3 \mathrm{a}$ & $56 \mathrm{~b}$ & $5 \mathrm{c}$ \\
\hline & Post-treatment & 73 & 26 & 23 & 39 & 0.5 & 43 & 7 \\
\hline \multirow{2}{*}{2} & Pre-treatment & 68 & 18 & 10 & 57 & $0.2^{\mathrm{a}}$ & $40^{\mathrm{b}}$ & $5^{c}$ \\
\hline & Post-treatment & 63 & 27 & 42 & 38 & 1.1 & 33 & 8 \\
\hline \multirow{2}{*}{3} & Pre-treatment & 50 & 17 & 24 & 31 & $0.8 \mathrm{a}$ & 13 & $2 \mathrm{c}$ \\
\hline & Post-treatment & 66 & 27 & 36 & 24 & 1.5 & 11 & 7 \\
\hline Normal Control & & $78 \pm 7$ & $16 \pm 7$ & $39 \pm 9.1$ & $35 \pm 8.7$ & $1.1(\mathrm{p}<0.05)^{\mathrm{a}}$ & $11 \pm 4(p<0.002)^{b}$ & $16 \pm 3(\mathrm{p}<0.02)^{\mathrm{c}}$ \\
\hline
\end{tabular}

\section{Discussion}

Our current knowledge about the pathophysiology, pathogenesis, and definite treatment of HIE Syndrome (JOB's) is limited. A major disbalance and altered immune responses are implicated in HIE patients. Some of the immune disorders are due to defects in the activator of transcription (JAK-STAT) signaling pathway in the autosomal dominant Hyper-IgE, which is activated by interleukin IL-6 and IL-2. This defect leads to impaired T cell helper type Th17 [3]. Though at present the immunosuppressant drug CSA has been widely used to prevent allograft rejection its successful use to treat variety of skin diseases particularly psoriasis and severe atopic eczema has also been reported [24-31]. CSA is a potent inhibitor of $\mathrm{T}$ cell activation and subsequent production of various immune mediators namely IL-2, IL-4 and IFN- $\gamma$ [32-35]. IL-4, IL-5 and IL-13 have been shown to mediate IgE synthesis in human involving a complex interaction among $\mathrm{B}$ cells, T cells and monocytes [36-39]. The whole cascade of IgE production can be modulated positively or negatively by cytokines. To elucidate the underlying immunological mechanism in HIE patients, we have presented the results of immunophenotyping, proliferative response of PBMC to PHA, PWM and IL-2, cytotoxicity level of NK cells, levels of various cytokines and immunoglobulins before and after low dose if CSA treatment of three HIE patients.

In response to low dose (60 - $200 \mu \mathrm{g} / \mathrm{ml}$ Plasma level) CSA treatment, the results of immunoglobulins quantitation showed a remarkable drop in the IgE level in all three patients without any adverse effects of $\operatorname{IgM}, \operatorname{IgG}$ and IgA immunoglobulins. It is a well accepted phenomenon in mice that subsets of helper T cells, Th1 and Th2, are responsible for differential production of cytokines [40]. Th1 clone when stimulated with appropriate stimulus can produce IL-2, IFN- $\gamma$ and TNF- $\alpha$; whereas Th2 clone produces IL-4, IL-5, IL-6, and IL-10. IFN- $\gamma$ has been shown to be a very important mediator in curtailing the production of IgE, whereas IL-4 molecules support the primary induction and production of $\operatorname{IgE}[6,41-43]$. A similar dichotomy among human $\mathrm{T}$ lymphocyte function has been observed in vitro [44]. Our results of flow cytometric analysis are supportive of this notion since absolute number of $\mathrm{T}$ and $\mathrm{B}$ lymphocytes in HIE patients were not altered, but rather a low T4:T8 ratio was observed in the pre-treated patients. The results of proliferative response to PHA, PWM, and IL-2 indicated inherent defect in either T cell or T cells bearing receptor for IL-2 in HIE patients. The NK cell dependent cytotoxicity in all the three pre-treated patients was substantially low as compared to normal control. An earlier study by Wehrmann et al., demonstrated the number and function of NK cells were altered in atopic patients with high level of circulating IgE [45]. The results of our in vitro study have shown that $\operatorname{IgE}$ at higher concentration can decrease regulative killer lineage cells function, implicating similar role of $\operatorname{IgE}$ in HIE patients [46]. Our results of impaired PHA response are in disagreement with earlier work. However the response of PWM in HIE patients has been controversial, we found mild to severe suppression of PWM proliferative response prior to CSA treatment with a tendency to improve with CSA treatment [13]. The results of cytokines measurement in our study indicate that IL- $1 \alpha$, TNF- $\alpha$ and IL-2 do not play any significant role in the pathophysiology of HIE Syndrome. Recent reports by Mogensen and Ochs et al., found that susceptibility to infection is related in part to defect in Th17 which results in decreased neutrophil proliferation and chemotaxis decreased inflammation and susceptibility to Candida and bacteria infection $[3,47]$. The earlier in vitro findings using PMA to stimulate PBMC from HIE patients also showed that inducible IL-2 production is least affected in HIE patients [7]. Our findings of high level of IL-4 and IgE in HIE patients before treatment are confirmatory of previous studies [7]. The most striking findings of this study, after CSA treatment, are that levels of IgE and IL-4 dropped to normal control levels. Following CSA treatment, a sharp decrease to an undetectable level of IFN- $\gamma$ was observed $(\mathrm{P}>0.001)$.

Previous treatment of HIE patients with a variety of agents and immune modulators, including levamisole, cimetidine, transfer factor and ascorbic acid, isotretinoin, cromoglycate and repeated plasma pheresis, failed to induce long term clinical remissions in these patients $[9-15,48]$. Although interferon- $\gamma$ was shown in vitro to regulate the IgE production by PBMC form HIE patients, it had no significant clinical effect in treating these patients [41].

Whether this clinical improvement and the normalization of the immune imbalance in HIE patients following treatment with CSA is long lasting and void of serious complication, needs to be evaluated further. After two years of treatment, there is no evidence of any complications except mild hypertrichosis in one patient. On one occasion, the skin lesion flared up three days after CSA was stopped suggesting, at least, that the skin improvement is directly related to CSA therapy.

Recently, low dose cyclosporin-A has been used to treat cases of severe atopic dermatitis with no subsequent serious complications $[31,49,50]$. Similarly safe and beneficial results after treatment with CSA in a variety of dermatological disorders have been reported [51]. The response of patients with HIE syndrome and severe atopic dermatitis to low dose CSA suggests a common link between these disorders. Both have immune dysregulation, with over production of IgE, severe pruritus and recurrent skin infection with staph aureus. This link needs further investigations in order to uncover possible common mechanism for causing the syndrome. 
Though much work is to be done to elucidate the precise mechanism of beneficial effect of CSA treatment in HIE patients, the results discussed here are encouraging for the future use of CSA to treat HIE patients. The effects of a newly and highly immunosuppressive agent FK506 on the IL-4 induced IgE production is also being examined in vitro to find out if it has similar effect as of CSA.

\section{Acknowledgement}

The authors are indebted to Mrs. Eleonor T Barroga for her excellent secretarial assistance in preparing the manuscript.

\section{References}

1. Buckley RH, and Becker WG (1978) Abnormalities in the regulation of human IgE synthesis. Immunol Rev 41: 288-313.

2. Woeliner Woellner C, Gertz EM, Schäffer AA, Lagos M, Perro M, et al. Mutations in STAT3 and diagnostic guidelines for hyper-IgE syndrome. J Allergy Clin Immunol 125: 424-432.

3. Mogensen TH (2013) STAT3 and the Hyper-IgE syndrome: Clinical presentation, genetic origin, pathogenesis, novel findings and remaining uncertainties. JAKSTAT 2: 23435.

4. Gernez Y, Freeman AF, Holland SM, Garabedian E, Patel NC, et al. (2018) Autosomal Dominant Hyper-IgE Syndrome in the USIDNET Registry J Allergy Clin Immunol Pract 6: 996-1001.

5. Leung DY, Geha RS (1988) Clinical and immunologic aspects of the hyperimmunoglobulin E syndrome. Hematol Oncol Clin North Am 2: 81100 .

6. Pene J (1989) Regulatory Role of Cytokines and DC23 in the Human IgE antibody synthesis. Int Arch Allergy Immunol 90: 32-40.

7. Vercelli D, Jabara HH, Cunningham-Rundles C, Abrams JS, Lewis DB, et al. (1990) Regulation of Immunoglobulin (Ig)E Synthesis in the Hyper-IgE Syndrome. J Clin Invest 85: 1666-1671.

8. Alsum Z, Hawwari A, Alsmadi O, Al-Hissi S, Borrero E, et al. (2013) Clinical, immunological and molecular characterization of DOCK8 and DOCK8-like deficient patients: single center experience of twenty-five patients. J Clin Immunol 33: 55-67.

9. Businco L, Laurenti F, Rossi P, Galli E, Aiuti F (1981) A child with atopic features raise serum $\operatorname{IgE}$, and recurrent infection treated with levamisole. Arch Dis Child 56: 60-63.

10. Friedenberg WR, Marx JJ Jr, Hansen RL, Haselby RC (1979) Hyperimmunoglobulin E Syndrome: Response to transfer factor and ascorbic acid therapy. Clin Immunol Immunopathol 12: 132-136.

11. Mawhinney H, Killen M, Fleming WA, Roy AD (1980) The hyperimmunoglobulin E syndrome--A neutrophil chemotactic defect reversible by histamine H2 receptor blockade? Clin Immunol Immunopathol 17: 483491.

12. Leung DYM, Wood NL, Geha RS (1985) Reversal of cellular abnormalities in the hyper IgE syndrome following plasmapheresis. Clin Res 33: $161 \mathrm{~A}$

13. Geha RS, Leung DYM (1989) Hyper Immunoglobulin E Syndrome. Immunodef. Rev 1: 155-172.

14. Shuttleworth D, Holt PJA, Mathews N (1988) Hyper Immunoglobulin E syndrome: treatment with isotretinoin. Br J Dermatol 119: 93-99.

15. Yokota S, Mitsuda T, Shimizu H, Ibe M, Matsuyama S (1990) Cromoglycate treatment of patient with hyperimmunoglobulinaemia E syndrome. Lancet 335: 857-858.

16. Buckley RH (2001) The hyper-IgE syndrome. Clin Rev Allergy Immunol 20: $139-154$.
17. Sheerin KA, Buckley RH (1991) Antibody responses to protein, polysaccharide, and phi X174 antigens in the hyperimmunoglobulinemia E (hyper-IgE) syndrome. J Allergy Clin Immunol 87: 803-811.

18. Siegel AM, Stone KD, Cruse G, Lawrence MG, Olivera A, et al. (2013) Diminished allergic disease in patients with STAT3 mutations reveals a role for STAT3 signaling in mast cell degranulation. J Allergy Clin Immunol 132: 1388-1396.

19. Boyum A (1968) Isolation of mononuclear cells and granulocytes by one step centrifugation and of granulocytes by combining centrifugation and sedimentation at Ig. Scand J Clin Lab Invest 97: 77-98.

20. Kwaasi AA, Parhar RS, Harfi H, Tipirneni P, al-Sedairy ST (1992) Characterization of antigens and allergens of date palm (Phoenix dactylifera) pollen. Immunological assessment of atopic patients using whole extract or it fraction. Allergy 47: 535-44.

21. Parhar RS, Yagel S, Lala PK (1989) PGE2-mediated immunosuppression by first trimested human decidual cells blocks activation of maternal leukocytes in the decidua with potential anti-trophoblast activity. Cell Immunol 120: 61-74.

22. Parhar RS, Ernst P, Sheth KV, al-Sedairy S (1992) Anti-Tumor cytotoxic potential and effect on human bone marrow GM-CFU of human LAK cells generated in response to various cytokines. Eur Cytokine Netw 3: 299-306.

23. Bouchama A, Parhar RS, el-Yazigi A, Sheth K, al-Sedairy S (1991) Endotoxemia and release of Tumournecrosis factor and interleukin 1 alpha in acute heatstroke. J Appl Physiol 70: 2640-2644.

24. Borel JF, Feurer C, Magńee C, Stähelin H (1977) Effects of the new anti-lymphocytic peptide cyclosporin A in animals. Immunology 32: 10171025 .

25. Calne RY, White DJ, Evans DB, Thiru S, Henderson RG (1981) Cyclosporin A in cadaveric organ transplantation. Br Med J (Clin Res Ed) 282: 934-936.

26. Calne RY, Rolles K, White DJ, Thiru S, Evans DB, et al. (1979) Cyclosporin A initially as the only immunosuppressant in 34 recipients of cadaveric organs: 32 kidneys, 2 pancreases, and 2 livers. Lancet 2: 1033-1036.

27. Starzl TE, Klintmalm GB, Porter KA, Iwatsuki S, Schröter GP (1981) Liver transplantation with use of cyclosporin a and prednisone. N Engl J Med 305: 266-269.

28. Kahan BD (1989) Cyclosporine. The New England Journal of Medicine 321: $1725-1738$

29. Biren CA, Barr RJ (1986) Dermatologic applications of cyclosporine. Arch Dermatol 122: 1028-1032.

30. Griffiths CE, Powles AV, Leonard JN, Fry L, Baker BS, et al. (1986) Clearance of psoriasis with low dose cyclosporin. Br Med J (Clin Res Ed) 293: 731-732.

31. Van Joost T, Stolz E, Meule F (1987) Efficacy of low dose cyclosporine in severe atopic skin disease. Arch Dermatol 123: 166-167.

32. Britton S, Palacios R (1982) Cyclosporin A-Useful, risks and mechanism of action. Immunol Rev 65: 5-22.

33. Bunjes D, Hardt C, Röllinghoff M, Wagner H (1981) Cyclosporin A mediates immunosuppression of primary cytotoxic $\mathrm{T}$ cell responses by impairing the release of interleukin 1 and interleukin 2. Eur J Immunol 11: 657-661.

34. Reem GH, Cook LA, Vilcek J (1983) Gamma interferon synthesis by human thymocytes and T lymphocytes inhibited by cyclosporin A. Science 221: 63-65.

35. Wang SC, Zeevi A, Jordan ML, Simmons RL, Tweardy DJ (1991) FK 506, rapamycin, and cyclosporine: effects on IL-4 and IL-10 mRNA levels in a T-helper 2 cell line. Transplant Proc 23: 2920-2922. 
36. DeKruff RH, Turner T, Abrams JS, Palladine MA, Umetsu DT (1989) Induction of human IgE synthesis by $\mathrm{CD} 4+\mathrm{T}$ cell clones. Requirement for interleukin 4 and low molecular weight B cell growth factor. J Exp Med 170: $1477-1494$

37. Ishizaka A, Sakiyama Y, Nakanishi M, Tomizawa K, Oshika E, et al (1990) The inductive effect of interleukin-4 on IgG4 and IgE synthesis in human peripheral blood lymphocytes. Clin Exp Immunol 79: 392-396.

38. Rousset F, Robert J, Andary M, Bonnin JP, Souillet G, et al. (1991) Shifts in interleukin-4 and interferon-gamma production by $\mathrm{T}$ cells of patients with elevated serum IgE levels and the modulatory effects of these lymphokines on spontaneous IgE synthesis. J Allergy Clin Immunol 87: 58-69.

39. Romagnani S, Maggi E, Del Prete G, Parronchi P, Tiri A, et al. (1989) Role of interleukins in induction and regulation of human IgE. Clin Exp Rheumatol 7: 117-122.

40. Coffman RL, Seymour BW, Lebman DA, Hiraki DD, Christiansen JA, et al. (1988) The role of helper T cell products in mouse B cell differentiation and isotype regulation. Immunol Rev 102: 5-28.

41. King CL, Gallin JI, Malech HL, Abramson SL, Nutman TB (1989) Regulation of immunoglobulin production in hyperimmunoglobulin E recurrent-infection syndrome by interferon gamma. Proc Natl Acad Sci USA 86: $10085-10089$

42. Ishizaka A, Joh K, Shibata R, Wagatsuma Y, Nakanishi M, et al. (1990) Regulation of IgE and IgG4 synthesis in patients with hyper IgE syndrome. Immunology 70: 414-416.

43. Gauchat JF, Lebman DA, Coffman RL, Gascan H, de Vries JE (1990) Structure and expression of germline epsilon transcripts in human B cells induced by interleukin 4 to switch to IgE production. J Exp Med 172: 463-473.
44. Del Prete G, Maggi E, Parronchi P, Chrétien I, Tiri A, et al. (1988) IL-4 is an essential factor for the IgE synthesis induced in vitro by human $\mathrm{T}$ cell clones and their J Immunol 140: 4193-4198.

45. Wehrmann W, Reinhold U, Kuekl S, Franke N, Uerlich M, et al. (1990) Selective Alternation in natural killer cell subsets in patients with atopic dermatitis. Int Arch Allergy Appl. Immunol 92: 318-322.

46. Parhar RS, Ernst P, Al-Mohanna F, Kwaasi A, Sheth KV, et al. (1991) 425 In vitro regulation of immune cell functions by human IgE. J Allergy and Clinical Immunol 87: 2-246.

47. Ochs HD, Oukka M, Torgerson TR (2009) TH17 cells and regulatory T cells in primary immunodeficiency diseases. J Allergy Clin Immunol 123: 977-983.

48. Donabedian H, Alling DW, Gallin JI (1982) Levamisole is inferior to placebo in the hyperimmunoglobulin E recurrent-infection (Job's) syndrome. N Engl J Med 307: 290-292.

49. Logan RA, Camp RD (1988) Severe atopic eczema: response to oral cyclosporin A. J R Soc Med 81: 417-418.

50. Taylor RS 3rd, Cooper KD, Headingto JT, Ho VC, Ellis CN, et al. (1989) Cyclosporine therapy for severe atopic dermatitis. J Am Acad Dermatol 21: 580-583.

51. Ho VC, Lui H, McLean DI (1990) Cyclosporine in nonpsoriatic dermatoses. J Am Acad Dermatol 23: 1248-1259. 


\section{Hit \\ HERALD}

Journal of Anesthesia \& Clinical Care

Journal of Addiction \& Addictive Disorders

Advances in Microbiology Research

Advances in Industrial Biotechnology

Journal of Agronomy \& Agricultural Science

Journal of AIDS Clinical Research \& STDs

Journal of Alcoholism, Drug Abuse \& Substance Dependence

Journal of Allergy Disorders \& Therapy

Journal of Alternative, Complementary \& Integrative Medicine

Journal of Alzheimer's \& Neurodegenerative Diseases

Journal of Angiology \& Vascular Surgery

Journal of Animal Research \& Veterinary Science

Archives of Zoological Studies

Archives of Urology

Journal of Atmospheric \& Earth-Sciences

Journal of Aquaculture \& Fisheries

Journal of Biotech Research \& Biochemistry

Journal of Brain \& Neuroscience Research

Journal of Cancer Biology \& Treatment

Journal of Cardiology \& Neurocardiovascular Diseases

Journal of Cell Biology \& Cell Metabolism

Journal of Clinical Dermatology \& Therapy

Journal of Clinical Immunology \& Immunotherapy

Journal of Clinical Studies \& Medical Case Reports

Journal of Community Medicine \& Public Health Care

Current Trends: Medical \& Biological Engineering

Journal of Cytology \& Tissue Biology

Journal of Dentistry: Oral Health \& Cosmesis

Journal of Diabetes \& Metabolic Disorders

Journal of Dairy Research \& Technology

Journal of Emergency Medicine Trauma \& Surgical Care

Journal of Environmental Science: Current Research

Journal of Food Science \& Nutrition

Journal of Forensic, Legal \& Investigative Sciences

Journal of Gastroenterology \& Hepatology Research
Journal of Gerontology \& Geriatric Medicine

Journal of Genetics \& Genomic Sciences

Journal of Hematology, Blood Transfusion \& Disorders

Journal of Human Endocrinology

Journal of Hospice \& Palliative Medical Care

Journal of Internal Medicine \& Primary Healthcare

Journal of Infectious \& Non Infectious Diseases

Journal of Light \& Laser: Current Trends

Journal of Modern Chemical Sciences

Journal of Medicine: Study \& Research

Journal of Nanotechnology: Nanomedicine \& Nanobiotechnology

Journal of Neonatology \& Clinical Pediatrics

Journal of Nephrology \& Renal Therapy

Journal of Non Invasive Vascular Investigation

Journal of Nuclear Medicine, Radiology \& Radiation Therapy

Journal of Obesity \& Weight Loss

Journal of Orthopedic Research \& Physiotherapy

Journal of Otolaryngology, Head \& Neck Surgery

Journal of Protein Research \& Bioinformatics

Journal of Pathology Clinical \& Medical Research

Journal of Pharmacology, Pharmaceutics \& Pharmacovigilance

Journal of Physical Medicine, Rehabilitation \& Disabilities

Journal of Plant Science: Current Research

Journal of Psychiatry, Depression \& Anxiety

Journal of Pulmonary Medicine \& Respiratory Research

Journal of Practical \& Professional Nursing

Journal of Reproductive Medicine, Gynaecology \& Obstetrics

Journal of Stem Cells Research, Development \& Therapy

Journal of Surgery: Current Trends \& Innovations

Journal of Toxicology: Current Research

Journal of Translational Science and Research

Trends in Anatomy \& Physiology

Journal of Vaccines Research \& Vaccination

Journal of Virology \& Antivirals

Submit Your Manuscript: http://www.heraldopenaccess.us/Online-Submission.php 